\title{
Analysis on the Influence and Cause of a Heavy Pollution Process on Air Quality in Baoding during COVID-19
}

\author{
Jie Li ${ }^{1,2}$, Kai Zhang", Xi Zhang³, Wen-li Lv², Yin-yin Gou ${ }^{1,2}$, \\ Min-kang Zhi ${ }^{2}$, Jin-juan Li ${ }^{1 * *}$ \\ ${ }^{1}$ College of Resources and Environmental Engineering, Guizhou University, Guiyang 550025, China \\ ${ }^{2}$ State Key Laboratory of Environmental Standards and Risk Assessment, \\ Chinese Research Academy of Environmental Sciences, Beijing 100012, China \\ ${ }^{3}$ Faculty of Environmental Engineering, The University of Kitakyushu, \\ 1-1 Hibikino, Wakamatsu, Kitakyushu, Fukuoka 808-0135, Japan
}

Received: 14 December 2020

Accepted: 27 July 2021

\begin{abstract}
Due to the outbreak of the novel coronavirus, China had implemented a strict home isolation policy after the Spring Festival, and human activities in many areas had been prohibited. However, Baoding still suffered heavy air pollution during February 2020, especially in February 8-13. The results showed that the concentrations of pollutants in February 2020 had a decrease from February 2019. The reduction of human activities during the epidemic significantly decreased the concentration of air pollutants and improved air quality. In addition, compared with non-pollution period (February 22-29), the $\mathrm{PM}_{2.5}$ concentration during pollution period (February 8-13) increased the most visibly. The analysis of OC and EC shows that there was a certain amount of civil coal combustion during the heavy pollution period; $\mathrm{K}^{+}$and $\mathrm{Mg}^{2+}$ in $\mathrm{PM}_{2.5}$ revealed the huge influence of fireworks and firecrackers in Baoding. The backward trajectory and potential source analysis indicated that Baoding was influenced by air masses from southwest during the heavy pollution period, and the potential source areas were mainly distributed in southwest of Baoding. It can be seen that the impact of pollutants in the superimposed area of local emission and transportation with unfavorable meteorological condition in Baoding.
\end{abstract}

Keywords: COVID-19, heavy pollution period, local emission, reginal, meteorological condition

\section{Introduction}

According to the rapid development of the economy with substantial energy consumption in past decades,

*e-mail: zhangkai@craes.org.cn

**e-mail: summy_lee@163.com
China is suffering severe air pollution [1-6]. To improve air quality, Chinese government published and implemented the Air Pollution Prevention and Control Action Plan in September 2013 [7, 8]. One of the important goals in this plan is that the concentrations of fine particulate matter $\left(\mathrm{PM}_{2.5}\right)$ in Jing-Jin-Ji shall decrease by $25.0 \%$ at the end of 2017 compared with 
2012. In order to fulfill the goal, a series measures, like enhancing industrial and vehicle emission standards, closing small and polluting factories, and upgrading industrial boilers, were conducted. [9-11]. As a result, the severe particulate pollution days were decreased from 122 in 2013 to 31 in 2017 within Jing-Jin-Ji [12].

There are many reasons for the formation of heavy pollution incidents: meteorological conditions [13-17], regional transmission, local emissions [18-20], etc. During heavy pollution period, meteorological conditions often play an extremely important role in the formation, transmission, deposition and transformation of pollutants in the atmosphere [21-23]. Local emissions and regional transmission will also have a significant impact on the atmospheric environment. Pollution tends to increase with unfavorable meteorological conditions. Previous studies showed that strong measures were taken in Beijing and nearby cities during the Asia Pacific Economic Cooperation (APEC) from October $20^{\text {th }}$ to $25^{\text {th }}, 2014$ and the Grand Military Parade (Parade) from August $15^{\text {th }}$ to September $15^{\text {th }}, 2015$, including closed factories and building sites, traffic controls, and six days off for some enterprises and institutions, to reduce the effects of anthropogenic emissions on the atmospheric environment [24-27], as a result, the air quality was notably improved [28-31]. Meanwhile, $\mathrm{PM}_{25}$ concentrations in Beijing fell by $51.6-65.1 \%$ and $34.2-64.7 \%$ respectively compared with the period without these measures.

China began to be affected by the novel coronavirus epidemic in late January 2020, and unofficial transportation in and out of Wuhan was closed on
January 23. In order to prevent the rapid spread of the epidemic and block the virus infection, other cities have begun to strictly implement the home isolation measures introduced by the state: construction sites have been suspended, enterprises have stopped production, vehicles on the road are scarce, and most people work from home as required. In February, when the epidemic was severe, due to the impact of epidemic prevention and control, various cities adopted strict control measures, reducing the emission of air pollutants and reducing the pollution process. The national air quality has significantly improved compared with last year. However, during the epidemic period, heavy pollution still occurred in some areas in China [1]. This situation has aroused heated discussion among the people and the attention of scholars.

Baoding, a city located in Hebei Province, experienced a long-term heavy air pollution process from February 8 to 13,2020 . This study is based on the online data of $\mathrm{PM}_{10}, \mathrm{PM}_{2.5}, \mathrm{SO}_{2}, \mathrm{NO}_{2}, \mathrm{CO}$ and $\mathrm{O}_{3}-8 \mathrm{~h}$, $\mathrm{OC} / \mathrm{EC}$ and water-soluble ions in $\mathrm{PM}_{2.5}$ to analyze the pollution characteristics of this heavy pollution process, and examine the causes of meteorological conditions and pollution sources in heavy pollution period.

\section{Data and Method}

\section{Monitoring Location and Time}

As shown in Fig. 1, the sampling campaign was carried out at Sunshine North Street in Baoding

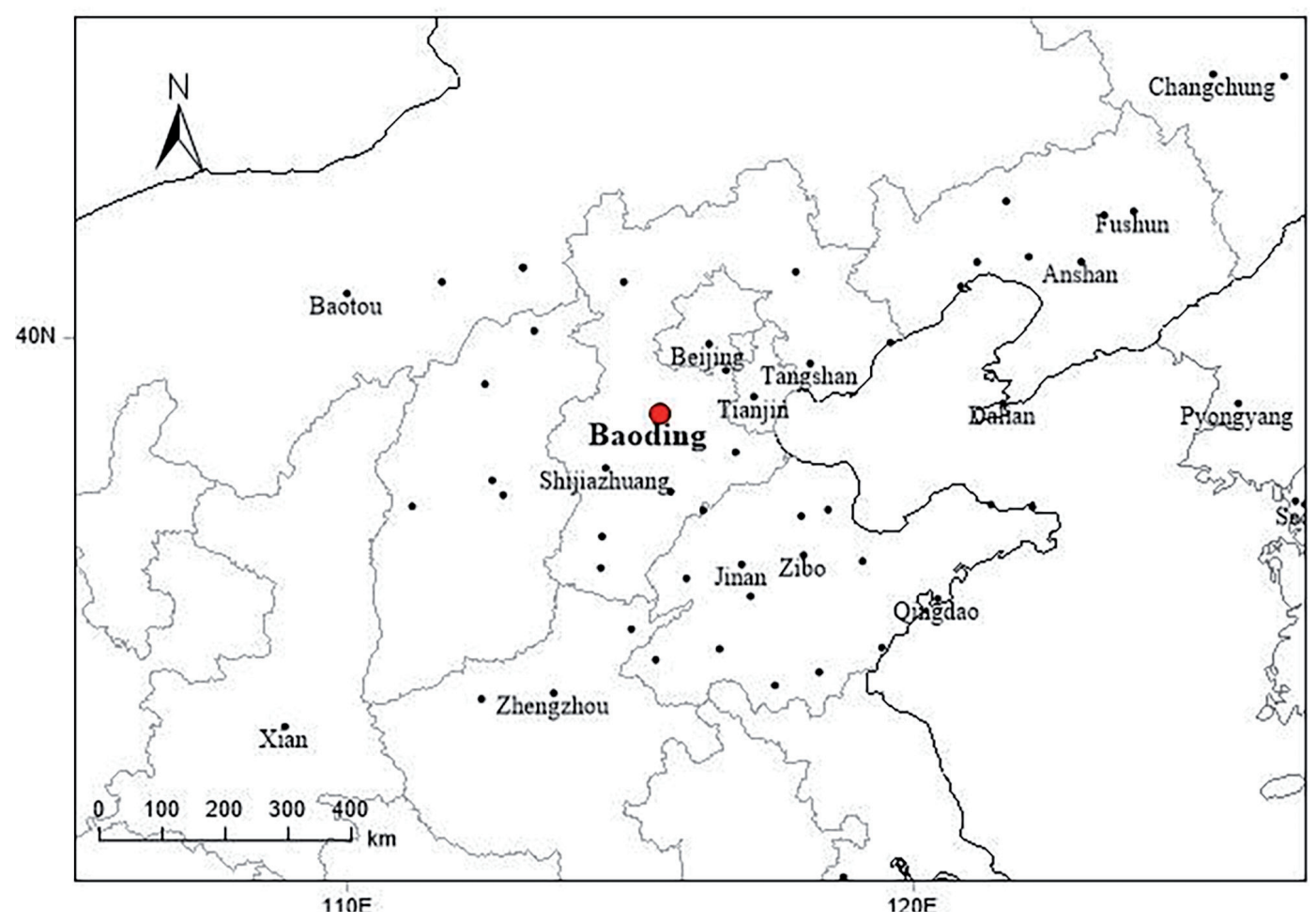

Fig. 1. Location map of Baoding. 
$\left(38.900742^{\circ} \mathrm{N}, 115.480812^{\circ} \mathrm{E}\right)$, located in the BeijingTianjin-Hebei Region, one of the most heavily polluted parts in China. The center of Baoding is 140 kilometers far from Beijing, 145 kilometers from Tianjin, and 125 kilometers from Shijiazhuang, the capital of Hebei Province. It lies in the north of the eastern foothills of the Taihang Mountains and the west of the Central Hebei Plain, and the terrain slopes from northwest to southeast, composed of three landforms: mountain, plain and hill. The surface airflow in this region is greatly affected by Taihang Mountains. Baoding is also a major city in the Southwest Corridor area that has an important impact on Beijing's air quality. The investigation of Baoding's atmosphere is, therefore, crucial to the environmental research of the region.

The monitoring time was from February 1 to 29, 2020 and February 1 to 28, 2019. Based on the Air Quality Index (AQI), the particulate matter, sulfur dioxide, nitrogen dioxide, carbonic oxide, and ozone were taken into account, the period from February 8 to 13 was defined as the heavy pollution period (AQI $>200$ ), the period from February 22 to 29 was defined as the non-pollution period $(\mathrm{AQI}<200$, the pollution in that time got closer to the monthly average degree of pollution in Baoding).

Affected by the epidemic, Baoding had adopted strict home isolation measures, so emissions from transportation sources and industrial sources had been drastically reduced, and pollution caused by increased residential heating was the main source of pollution during heavy pollution period.

\section{Data Sources}

The mass concentration monitoring data of $\mathrm{PM}_{10}, \mathrm{PM}_{2.5}, \mathrm{SO}_{2}, \mathrm{NO}_{2}, \mathrm{CO}$ and $\mathrm{O}_{3}-8 \mathrm{~h}$ in Baoding, Shijiazhuang, Tangshan, Langfang, Xingtai, Cangzhou, Hengshui and Handan were obtained from comprehensive data collection and sharing platform for atmospheric environmental science (https://napcdata. craes.cn). The data of water-soluble ions and $\mathrm{OC} / \mathrm{EC}$ in $\mathrm{PM}_{25}$ were provided by national atmospheric particulate matter composition and photochemical monitoring data integration and comprehensive analysis platform (http://106.37.208.242:30005/cnemc/login). Before using these data effective data screening was carried out to ensure the reliability of analysis results. In addition, the meteorological data was provided by Global Date Assimilation System (GDAS), and the pollution source data was from the Emission Inventory of Baoding in 2018 by Chinese Research Academy of Environmental Sciences.

\section{Analysis Method \\ Analysis of $O C / E C$}

For the carbonaceous species, primary organic carbon (POC), secondary organic carbon (SOC), and total carbonaceous aerosols (TCA) were calculated as follows:

$$
\begin{gathered}
\mathrm{POC}=\mathrm{EC} \times(\mathrm{OC} / \mathrm{EC})_{\min } \\
\mathrm{SOC}=\mathrm{OC}-\mathrm{POC} \\
\mathrm{TCA}=\mathrm{f} \times \mathrm{OC}+\mathrm{EC}
\end{gathered}
$$

...where (OC/EC) min was the minimum ratio of OC/EC (dimensionless) during the monitoring period [32], and f was adopted as 1.6 to convert $\mathrm{OC}$ to organic matter (OM) [33].

\section{Backward Trajectory and Potential Source Analysis}

The 24-hr backward trajectories were generated by TrajStat software based on GDAS data, with the arriving height and top of the model of 500 and 10,000 $\mathrm{m}$, respectively. Cluster analysis takes the study area as the starting point, and pushes back the airflow at a height of $500 \mathrm{~m}$ above the ground every 1 hour to obtain multiple airflow trajectories and analyze the clusters. Then the cluster analysis and Concentration Weighted Trajectory (CWT) analysis were performed in this study to investigate the transport pathways and potential sources of $\mathrm{PM}_{2.5}$ [34-38]. The calculation formula is as follows:

$$
\mathrm{C}_{\mathrm{ij}}=\frac{\sum_{\mathrm{l}=1}^{\mathrm{M}} \mathrm{C}_{\mathrm{l}} \cdot \tau_{\mathrm{ijl}}}{\sum_{\mathrm{l}=1}^{\mathrm{M}} \tau_{\mathrm{ijl}}}
$$

...where $\mathrm{C}_{\mathrm{ij}}$ is the average weighted pollutant concentration in the ij cell, 1 is the index of the trajectory, $\mathrm{M}$ is the total number of trajectories, $\mathrm{C}_{1}$ is the pollutant concentration observed on the arrival trajectory $1, \tau_{\mathrm{ijl}}$ is the residence time of trajectory 1 in ij cell.

\section{Results and Discussion}

\section{Analysis of Pollution Characteristics}

The average concentrations of $\mathrm{PM}_{10}, \mathrm{PM}_{2.5}$, $\mathrm{SO}_{2}, \mathrm{NO}_{2}, \mathrm{CO}$, and $\mathrm{O}_{3}-8 \mathrm{~h}$ during sampling period (February, 2020) in Baoding City were: $99 \pm 67 \mu \mathrm{g} \cdot \mathrm{m}^{-3}$, $77 \pm 58 \mu \mathrm{g} \cdot \mathrm{m}^{-3}, 10 \pm 3 \mu \mathrm{g} \cdot \mathrm{m}^{-3}, 27 \pm 11 \mu \mathrm{g} \cdot \mathrm{m}^{-3}, 2.5 \pm 0.7 \mathrm{mg} \cdot \mathrm{m}^{-3}$, and $91 \pm 24 \mu \mathrm{g} \cdot \mathrm{m}^{-3}$. Compared with that in February, 2019, the concentrations of $\mathrm{SO}_{2}, \mathrm{NO}_{2}, \mathrm{PM}_{10}$, and $\mathrm{PM}_{2.5}$ varied obviously, with the decreasing rate of $44.4 \%, 42.6 \%, 38.9 \%$, and $33.0 \%$, respectively. This phenomenon was related to the influence of limiting human activities during COVID-19 on the corresponding source emissions. To be specific, the $\mathrm{SO}_{2}$ concentration in Baoding was decreased significantly because of the implemented clean heating and coalfired boiler treatment implemented in recent years [10], 
and the suspension of production during the epidemic of COVID-19. For $\mathrm{NO}_{2}$, most transportation and mobile vehicles were prohibited all around Baoding during COVID-19, causing the obvious decrease of $\mathrm{NO}_{2}$ concentration. It meant the measurement had enormous impact in Baoding. This phenomenon is consistent with previous studies [39-42]. According to the Emission Inventory of Baoding in 2018, dust sources accounted for the largest proportion of the total source of $\mathrm{PM}_{10}$, reaching $48.0 \%$. Road dust accounted for the largest proportion (31.0\% of $\mathrm{PM}_{10}$ sources), followed by construction dust (11.0\%). During the epidemic of COVID-19, the number of motorized vehicles on the roads was greatly reduced, and the construction activities were stopped, finally causing the significant decrease of $\mathrm{PM}_{10}$ concentration.

\section{Analysis of Concentration Characteristics of Pollutants in Heavy Pollution Period}

During the heavy pollution process in Baoding (February 8 to 13, 2020), the highest Air Quality Index (AQI) hourly value reached 310 . The concentrations of $\mathrm{PM}_{10}, \mathrm{PM}_{2.5}, \mathrm{SO}_{2}, \mathrm{NO}_{2}, \mathrm{CO}$, and $\mathrm{O}_{3}-8 \mathrm{~h}$ during the heavy pollution period were $215 \pm 39 \mu \mathrm{g} \cdot \mathrm{m}^{-3}, 181 \pm 34 \mu \mathrm{g} \cdot \mathrm{m}^{-3}$, $13 \pm 3 \mu \mathrm{g} \cdot \mathrm{m}^{-3}, \quad 38 \pm 12 \quad \mu \mathrm{g} \cdot \mathrm{m}^{-3}, \quad 2.8 \pm 0.4 \quad \mathrm{mg} \cdot \mathrm{m}^{-3}$ and $111 \pm 35 \mu \mathrm{g} \cdot \mathrm{m}^{-3}$, while their concentrations during the non-pollution period were $71 \pm 35 \mu \mathrm{g} \cdot \mathrm{m}^{-3}, 49 \pm 26 \mu \mathrm{g} \cdot \mathrm{m}^{-3}$, $11 \pm 5 \mu \mathrm{g} \cdot \mathrm{m}^{-3}, \quad 28 \pm 11 \mu \mathrm{g} \cdot \mathrm{m}^{-3}, \quad 1.4 \pm 0.4 \mu \mathrm{mg} \cdot \mathrm{m}^{-3}$, and $80 \pm 19 \mu \mathrm{g} \cdot \mathrm{m}^{-3}$, respectively. The concentrations of $\mathrm{PM}_{10}$, $\mathrm{PM}_{2.5}, \mathrm{SO}_{2}, \mathrm{NO}_{2}, \mathrm{CO}$, and $\mathrm{O}_{3}-8 \mathrm{~h}$ during the heavy pollution period were 3.0 times, 3.7 times, 1.2 times, 1.4 times, 2.0 times and 1.4 times that of the non- pollution period, and the $\mathrm{PM}_{2.5}$ concentration increased the most, followed by $\mathrm{PM}_{10}$ and $\mathrm{CO}$. The concentrations of $\mathrm{PM}_{10}$ and $\mathrm{PM}_{2.5}$ both exceeded the national secondary standards (GB3095-2012, secondary standards: $\left.\rho\left(\mathrm{PM}_{10}\right) \leq 150 \mu \mathrm{g} \cdot \mathrm{m}^{-3}, \rho\left(\mathrm{PM}_{2.5}\right) \leq 75 \mu \mathrm{g} \cdot \mathrm{m}^{-3}\right)$.

Li et al. [43] analyzed a heavy pollution process in Taiyuan City from December 2016 to January 2017, revealing that $\mathrm{PM}_{2.5}, \mathrm{PM}_{10}$ and $\mathrm{SO}_{2}$ were the main contributors to the pollution incident; Li et al. [44] conducted a survey in Jinan, and the analysis of a typical heavy pollution process showed that the concentrations of $\mathrm{PM}_{10}$ and $\mathrm{PM}_{2.5}$ exceeded the national secondary standards by 3.5 times and 4.7 times, respectively. Most studies have shown that the concentration of particulate matter increased significantly during heavy pollution. Generally, severe air pollution events can be avoided by controlling anthropogenic emissions [45], however, the obvious increase of the concentration of particulate matter was observed during the epidemic of COVID-19 that all avoidable outdoor human activities stopped and most enterprises were closed (Fig. 2). Hence, further research is needed for particulate matter during heavy pollution.

As the air environment quality was mainly influenced by particulate matter, the diurnal variation of $\mathrm{PM}_{10}$ and $\mathrm{PM}_{2.5}$ during heavy pollution period were analyzed in this study, as shown in Fig. 3. The increase of particulate matter concentration during heavy pollution was principally occurred at night after 18:00, which was consistented with previous research [18]. This phenomenon was caused by people stayed in their homes and cooked. The demand for heating increased, the amount of coal burned also increased,

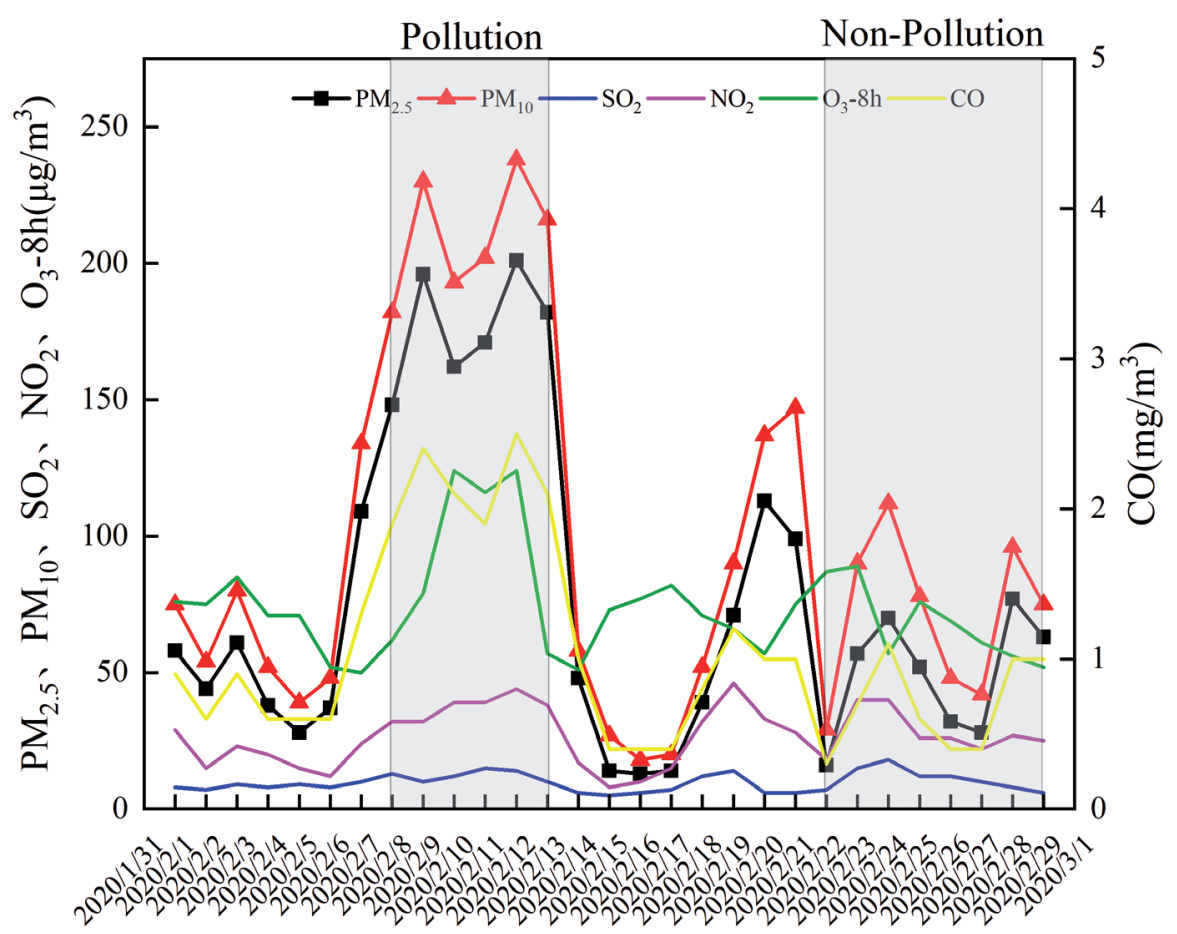

Fig. 2. Hourly changes in the concentration of pollutants in Baoding in February. 

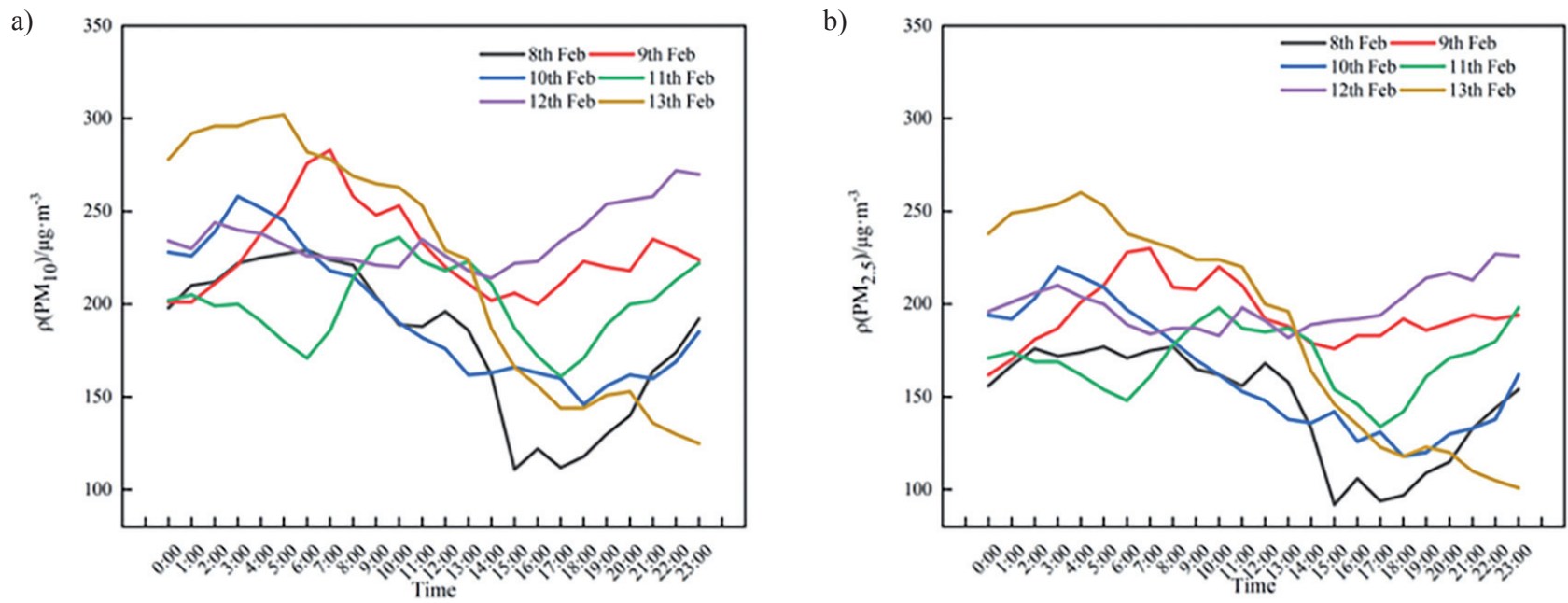

Fig. 3. Hourly concentrations of $\mathrm{PM}_{10}$ a) and $\mathrm{PM}_{2.5}$ b) in Baoding during the heavy pollution period in February 2020.

and the concentration of pollutants began to rise. On the other hand, the decline of the atmospheric boundary layer at night, the weakening of the environmental diffusion capacity, and the difficulty of the diffusion of pollutants, and the gradual accumulation. While in the daytime, the atmospheric boundary layer rose, and the spread of pollutants became larger; hence, the particle concentrations decreased gradually. As can be seen from Fig. 3, the concentration of particulate matter had been decrease significantly, and it did not increase after 18:00 in $13^{\text {th }}$ Feb., that might due to the meteorological conditions such as RH and wind speed had changed after 13th Feb., which conducive to the diffusion of pollutants.

\section{OC/EC in $\mathrm{PM}_{2.5}$}

The mass concentrations of $\mathrm{OC}$ and $\mathrm{EC}$ in $\mathrm{PM}_{25}$ during the heavy pollution period and the non-pollution period were $26.2 \pm 7.6 \mu \mathrm{g} \cdot \mathrm{m}^{-3}, \quad 6.5 \pm 1.9 \mu \mathrm{g} \cdot \mathrm{m}^{-3}$ and
$8.0 \pm 5.6 \mu \mathrm{g} \cdot \mathrm{m}^{-3}, \quad 2.2 \pm 1.4 \mu \mathrm{g} \cdot \mathrm{m}^{-3}$, respectively. The proportions in $\mathrm{PM}_{2.5}$ were $14.8 \%, 3.6 \%$ and $16.4 \%$, $4.6 \%$, respectively. The concentrations of OC and EC in $\mathrm{PM}_{2.5}$ during the heavy pollution period increased significantly compared with those during the nonpollution period. The concentration of OC and EC during the pollution period was 3.3 times and 2.9 times that of the non-polluted period, respectively. From Fig. 4, it can be seen that OC and EC in the two periods had strong correlation, with the $\mathrm{R}^{2}$ values of 0.8 and 0.8 , respectively. It confirmed that $\mathrm{OC}$ and $\mathrm{EC}$ in $\mathrm{PM}_{2.5}$ in Baoding may have the similar pollution source.

The correlation and ratio of $\mathrm{OC}$ and $\mathrm{EC}$ are often used as the basis for judging the source of carbonaceous aerosols [46]. If the ratio of $\mathrm{OC} / \mathrm{EC}>2$, it demonstrates that there is secondary pollution in the atmosphere. Studies have shown that when the OC/EC ratio is 1.0-4.2, it is vehicle exhaust emissions [47], 2.5-10.5 is coal combustion emissions, and 8.1-12.7 is biomass combustion [48]. The study by Woston et al. [49]
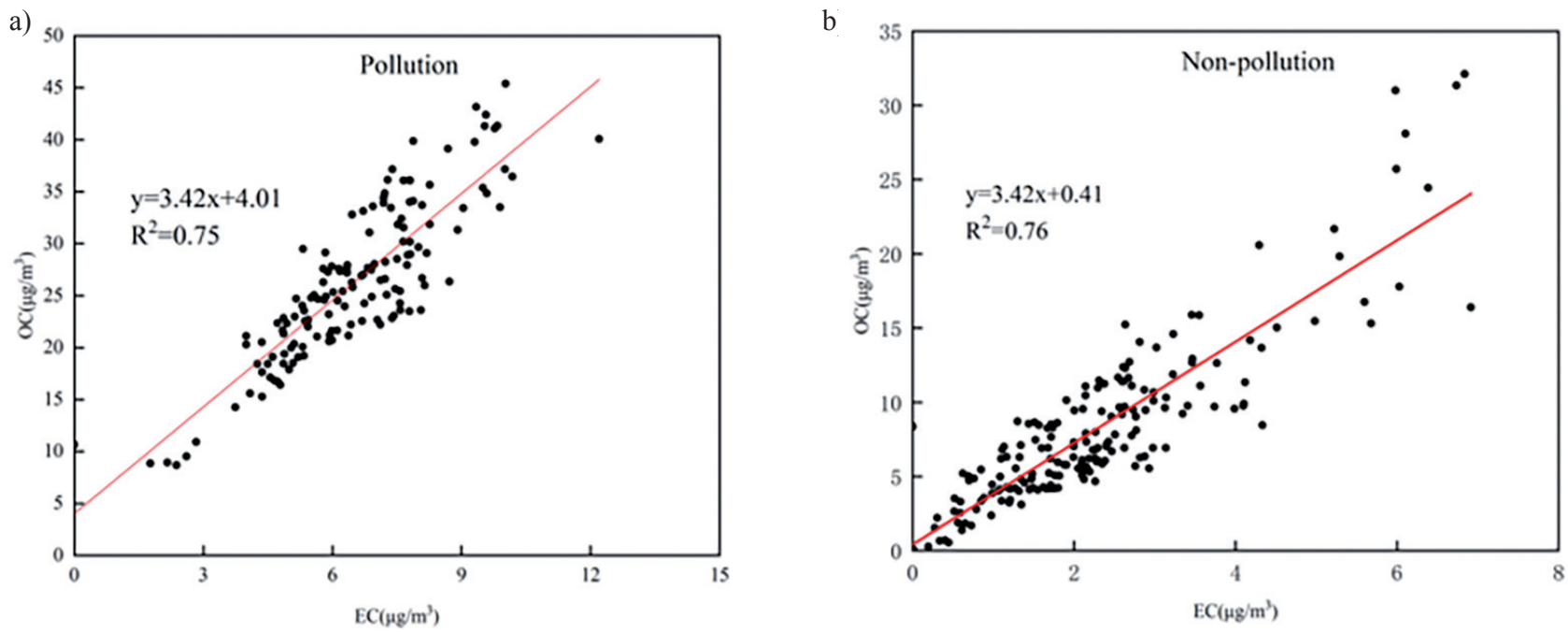

Fig. 4. Correlation of a) OC and b) EC between the pollution period and the non-pollution period. 
Table 1. The mass concentration of carbon component during the pollution period and the non-pollution period and the proportion in $\mathrm{PM}_{25}$.

\begin{tabular}{|c|c|c|c|c|c|c|c|c|}
\hline Period & $\begin{array}{c}\mathrm{PM}_{2.5} \\
\left(\mu \mathrm{g} \cdot \mathrm{m}^{-3}\right)\end{array}$ & $\begin{array}{c}\mathrm{OC} \\
\left(\mu \mathrm{g} \cdot \mathrm{m}^{-3}\right)\end{array}$ & $\begin{array}{c}\mathrm{EC} \\
\left(\mu \mathrm{g} \cdot \mathrm{m}^{-3}\right)\end{array}$ & $\mathrm{OC} / \mathrm{PM}_{2.5}$ & ${\mathrm{EC} / \mathrm{PM}_{2.5}}$ & $\begin{array}{c}\text { Average of } \\
\mathrm{OC} / \mathrm{EC}\end{array}$ & $\begin{array}{c}\mathrm{SOC} \\
\left(\mu \mathrm{g} \cdot \mathrm{m}^{-3}\right)\end{array}$ & $\mathrm{SOC} / \mathrm{OC}$ \\
\hline Pollution & $181 \pm 34$ & $26.2 \pm 7.6$ & $6.5 \pm 1.9$ & $14.8 \%$ & $3.6 \%$ & $4.1 \pm 0.6$ & 23.0 & $86.1 \%$ \\
\hline Non-pollution & $49 \pm 26$ & $8.0 \pm 5.6$ & $2.2 \pm 1.4$ & $16.4 \%$ & $4.6 \%$ & $3.7 \pm 1.3$ & 5.6 & $66.0 \%$ \\
\hline
\end{tabular}

showed that the $\mathrm{OC} / \mathrm{EC}$ ratio of coal-fired boilers is 1.38.1 , and the OC/EC ratio of civil bulk coal combustion is 2.7-5.25. In this study, the $\mathrm{OC} / \mathrm{EC}$ ratios during the heavy pollution period and non-pollution period were $4.1 \pm 0.6$ and $3.7 \pm 1.3$, respectively. Therefore, $\mathrm{PM}_{25}$ in Baoding in February came from the burning of civilian coal. It can be seen from Table 1 that the OC/EC of $\mathrm{PM}_{2.5}$ during the pollution period and the non-pollution period was greater than 2; thus there has huge influence of secondary pollution in February.

The mass concentration of TCA in Baoding during the heavy pollution period and the non-pollution period were $49.4 \mu \mathrm{g} \cdot \mathrm{m}^{-3}$ and $15.8 \mu \mathrm{g} \cdot \mathrm{m}^{-3}$, accounting for $27.3 \%$ and $32.3 \%$ of $\mathrm{PM}_{2.5}$ mass concentration, respectively, indicating that Baoding was polluted by a certain amount of carbonaceous aerosol in February. The average mass concentration of $\mathrm{SOC}$ in $\mathrm{PM}_{25}$ in Baoding during the heavy pollution period and the non-pollution period were $23.0 \mu \mathrm{g} \cdot \mathrm{m}^{-3}$ and $5.6 \mu \mathrm{g} \cdot \mathrm{m}^{-3}$, respectively, and the SOC/OC were $86.1 \%$ and $66.0 \%$, indicating that SOC accounted for a relatively high proportion of OC during the heavy pollution period. Studies have shown that stable atmosphere and low temperature will accelerate the conversion of semivolatile organic compounds in the atmosphere to SOC by condensation and condensation [50]. During this heavy pollution period, the average of relative humidity $(\mathrm{RH})$, temperature, and wind speed were $80.0 \%, 1.7^{\circ} \mathrm{C}$, $1.6 \mathrm{~m} / \mathrm{s}$, respectively. RH was high with maximum reaching $100 \%$, the wind speed was less than $6 \mathrm{~m} / \mathrm{s}$, and temperature was at $-7-15^{\circ} \mathrm{C}$, revealing the static and stable weather in Baoding city, which was similar to the above research situation, hence the same reaction should occur to promote the generation of SOC. According to the statistics of Baoding's 2018 emission inventory, the pollution caused by the burning of civil bulk coal accounted for $13.9 \%$. During this heavy pollution period, the proportion of carbonaceous components in $\mathrm{PM}_{2.5}$ slightly higher than in 2018 , it indicated that a certain amount of civil loose coal was burned during the heavy pollution.

\section{Distribution Characteristics of Water-Soluble Ions in $P M_{2,5}$}

The proportion of water-soluble ions in $\mathrm{PM}_{2.5}$ is also an important basis for analyzing the source of $\mathrm{PM}_{2.5}$. As shown in Table 2, during the heavy pollution period, the order of the average concentrations of water-soluble ions in $\mathrm{PM}_{2.5}$ was $\mathrm{SO}_{4}{ }^{2-}>\mathrm{NO}_{3}>\mathrm{NH}_{4}^{+}>\mathrm{Cl}^{-}>\mathrm{K}^{+}>\mathrm{Na}^{+}>\mathrm{Ca}^{2+}>\mathrm{Mg}^{2+}$.
Secondary inorganic ions, namely $\mathrm{SO}_{4}{ }^{2-}, \mathrm{NO}_{3}{ }^{-}$and $\mathrm{NH}_{4}^{+}$ (SNA) [51], were the main components of water-soluble ions in $\mathrm{PM}_{25}$, with the concentrations of $45.4 \pm 15.5 \mu \mathrm{g} \cdot \mathrm{m}^{-3}$, $44.9 \pm 20.1 \mu \mathrm{g} \cdot \mathrm{m}^{-3}$ and $31.0 \pm 8.8 \mu \mathrm{g} \cdot \mathrm{m}^{-3}$, respectively, and SNA accounted for $94.1 \%$ of the total water-soluble inorganic ion (WSI) concentration and $67.0 \%$ of the $\mathrm{PM}_{2.5}$ concentration. In addition, $\mathrm{Cl}^{-}$also had relative high concentration $\left(4.7 \pm 1.6 \mu \mathrm{g} \cdot \mathrm{m}^{-3}\right)$ during this heavy pollution period. It can be seen that SNA concentration had significantly increase that the concentrations of $\mathrm{SO}_{4}^{2-}, \mathrm{NO}_{3}^{-}$and $\mathrm{NH}_{4}^{+}$in the heavy pollution period were 4.8 times, 3.3 times and 4.3 times that of the nonpollution period, respectively. During APEC in 2014 and 2008 Olympic Games, Baoding had executed some tough policies to control the anthropogenic emissions, SNA in the total water-soluble inorganic ions of $\mathrm{PM}_{25}$ had decreased $82.4 \%$ and $92.0 \%$, respectively [52, 53]. The measures during COVID-19 were stricter than that during APEC in 2014 and 2008 Olympic Games, SNA in the total water-soluble inorganic ions of $\mathrm{PM}_{2.5}$ had increased to a certain extent during this heavy pollution. Different from the above two periods, Baoding experienced the Chinese Lantern Festival that would cause air pollution.

According to the time variation of water-soluble ions in Baoding in February 2020 (Fig. 5), it can be seen that the concentrations of cations such as $\mathrm{K}^{+}, \mathrm{Ca}^{2+}$ and $\mathrm{Mg}^{2+}$ have significantly increased, which were 9.5 times, 3.1 times and 4.3 times higher than those in the non-pollution period. Among them, the increase in $\mathrm{K}^{+}$concentration was the most apparent, followed by $\mathrm{Mg}^{2+}$. Many studies have shown that the setting off of fireworks and firecrackers will increase the plasma concentration of $\mathrm{K}^{+}, \mathrm{Mg}^{2+}$, and $\mathrm{Al}^{3+}$ in the particulate matter [54-55]. According to Pearson correlation calculations, during the heavy pollution period, the correlation between $\mathrm{K}^{+}$and $\mathrm{Cl}^{-}$attained 0.7 , which showed a strong correlation, indicating that the two ions had the same source. With the development of air pollution control in Baoding, the main urban areas of Baoding and the built-up areas of various districts and counties are prohibited from setting off fireworks [56], but the observed high concentrations of $\mathrm{K}^{+}$and $\mathrm{Mg}^{2+}$ in this study indicated that fireworks are still set off in rural Baoding. The peak time of fireworks was occurred on February 8, 2020, which was the traditional Chinese Lantern Festival. February 29 was a day that had no pollution without anthropogenic influence in non-pollution period. These two days can better represent the situation during the pollution 
Table 2. Mass concentration of ion components and the proportion in WSI/PM ${ }_{2.5}$.

\begin{tabular}{|c|c|c|c|c|c|c|}
\hline Component & $\begin{array}{c}\text { Pollution } \\
\left(\mu \mathrm{g} \cdot \mathrm{m}^{-3}\right)\end{array}$ & Ratio in WSI & Ratio in $\mathrm{PM}_{2.5}$ & $\begin{array}{c}\text { Non-pollution } \\
\left(\mu \mathrm{g} \cdot \mathrm{m}^{-3}\right)\end{array}$ & Ratio in WSI & Ratio in PM \\
\hline $\mathrm{Cl}^{-}$ & $4.7 \pm 1.6$ & $3.7 \%$ & $2.6 \%$ & $1.8 \pm 1.1$ & $5.4 \%$ & $3.7 \%$ \\
\hline $\mathrm{Ca}^{2+}$ & $0.5 \pm 1.2$ & $0.4 \%$ & $0.3 \%$ & $0.2 \pm 0.1$ & $0.5 \%$ & $0.4 \%$ \\
\hline $\mathrm{K}^{+}$ & $1.6 \pm 0.8$ & $1.2 \%$ & $0.9 \%$ & $0.2 \pm 0.1$ & $0.5 \%$ & $0.4 \%$ \\
\hline $\mathrm{Mg}^{2+}$ & $0.1 \pm 0.2$ & $0.1 \%$ & $0.1 \%$ & $0.03 \pm 0.02$ & $0.1 \%$ & $0.1 \%$ \\
\hline $\mathrm{Na}^{+}$ & $0.6 \pm 0.3$ & $0.5 \%$ & $0.4 \%$ & $0.4 \pm 0.1$ & $1.2 \%$ & $0.8 \%$ \\
\hline $\mathrm{NH}_{4}^{+}$ & $31.0 \pm 8.8$ & $24.1 \%$ & $17.1 \%$ & $7.3 \pm 5.4$ & $22.0 \%$ & $15.0 \%$ \\
\hline $\mathrm{NO}_{3}^{-}$ & $44.9 \pm 20.1$ & $34.8 \%$ & $24.8 \%$ & $13.8 \pm 9.2$ & $41.5 \%$ & $28.2 \%$ \\
\hline $\mathrm{SO}_{4}{ }^{2-}$ & $45.4 \pm 15.5$ & $35.2 \%$ & $25.1 \%$ & $9.6 \pm 10.2$ & $28.8 \%$ & $19.6 \%$ \\
\hline $\mathrm{SNA}^{-}$ & $121.3 \pm 33.6$ & $94.1 \%$ & $67.0 \%$ & $30.7 \pm 22.9$ & $92.3 \%$ & $62.8 \%$ \\
\hline $\mathrm{PM}_{2.5}$ & $181 \pm 34$ & - & & $49 \pm 26$ & & - \\
\hline
\end{tabular}

period and the non-pollution period. On February 8, the average concentrations of $\mathrm{SO}_{4}^{2-}, \mathrm{K}^{+}, \mathrm{Mg}^{2+}$, and $\mathrm{Cl}^{-}$ were $59.8 \mu \mathrm{g} \cdot \mathrm{m}^{-3}, 1.2 \mu \mathrm{g} \cdot \mathrm{m}^{-3}, 0.3 \mu \mathrm{g} \cdot \mathrm{m}^{-3}$ and $5.1 \mu \mathrm{g} \cdot \mathrm{m}^{-3}$, respectively, which were 2.4 times, 8.4 times, 126.0 times and 3.0 times higher than the average concentrations during the period of basically no fireworks and firecrackers. The concentration of $\mathrm{NO}_{3}^{-}$ and $\mathrm{NH}_{4}^{+}$changes did not exceed 2.0 times. Compared with basically no fireworks and firecrackers, the concentration of water-soluble ions in the peak hours of fireworks and firecrackers increased to a certain extent. Among them, the primary ions such as $\mathrm{K}^{+}, \mathrm{Mg}^{2+}$ and $\mathrm{Cl}^{-}$ increased obviously. Comparing the data from the same period in Shijiazhuang, Tangshan, Langfang and other cities, it found that the changes in the concentration of water-soluble ions $\mathrm{K}^{+}, \mathrm{Mg}^{2+}$ and $\mathrm{Cl}^{-}$in $\mathrm{PM}_{2.5}$ in Shijiazhuang were consistent with those in Baoding, but the changes in water-soluble ion concentrations in other cities were not significant. It indicated that the air in Baoding and Shijiazhuang cities was affected by fireworks during the heavy pollution period.

\section{Analysis of the Cause of Pollution}

\section{Comparative Analysis with Other Cities}

Comparing the daily AQI index of Baoding and other major cities in Hebei Province during the

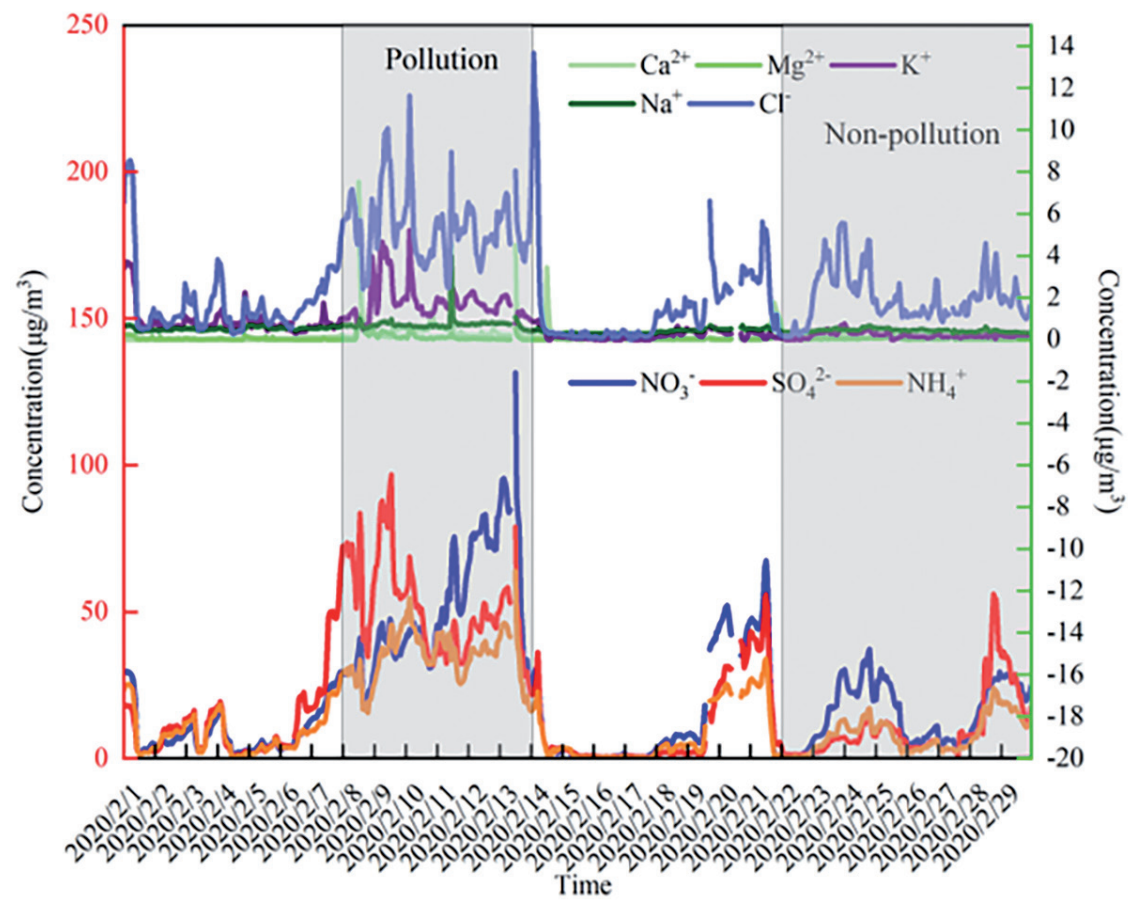

Fig. 5. Hourly change of water-soluble ions in $\mathrm{PM}_{2.5}$ in February 2020. 
Table 3. Concentrations of pollutants in 8 cities in Hebei Province from February 8 to $13\left(\mu \mathrm{g} \cdot \mathrm{m}^{-3}\right)$.

\begin{tabular}{|c|c|c|c|c|c|c|}
\hline Cities & $\mathrm{PM}_{10}$ & $\mathrm{PM}_{2.5}$ & $\mathrm{SO}_{2}$ & $\mathrm{NO}_{2}$ & $\mathrm{CO}\left(\mathrm{mg} / \mathrm{m}^{3}\right)$ & $\mathrm{O}_{3}$ \\
\hline Baoding & 210 & 177 & 12 & 37 & 2.5 & 124 \\
\hline Shijiazhuang & 179 & 137 & 16 & 37 & 2.4 & 128 \\
\hline Tangshan & 190 & 144 & 24 & 55 & 6.4 & 83 \\
\hline Handan & 121 & 92 & 13 & 28 & 2.3 & 110 \\
\hline Xingtai & 134 & 104 & 22 & 20 & 2.6 & 113 \\
\hline Langfang & 194 & 158 & 6 & 50 & 2.8 & 102 \\
\hline Cangzhou & 113 & 88 & 18 & 21 & 1.7 & 115 \\
\hline Hengshui & 94 & 76 & 10 & 15 & 1.2 & 118 \\
\hline
\end{tabular}

pollution period, it was found that the number of days when the daily AQI of Baoding reached 200 was 5 days, while in Langfang, Tangshan, Shijiazhuang, Handan and Xingtai were 4 days, 3 days, 3 days, 1 day, and 1 day, respectively. Cangzhou and Hengshui did not have heavy pollution days. The pollution with certain regional characteristics was mainly concentrated in the four cities, Baoding, Langfang, Tangshan and Shijiazhuang. Analyzing the meteorological conditions of Baoding and other major cities during the heavy pollution period, it can be found that the concentration of pollutants in the cities who had high AQI were higher than the others (Table 3). The cities with heavy pollution were in quiet and stable weather during this period, which was not conducive to the diffusion of pollutants. According to the characteristics of the heavy pollution process in Hebei Province in 2015, Zhu et al.
[57] found that the scope of heavy pollution was mainly concentrated in Baoding, Xingtai, Handan, Hengshui, Shijiazhuang in the south and Tangshan and Langfang in the east. The factor leading to this situation was the high regional emissions in Hebei Province, adverse weather conditions and special geographical location. In this heavy pollution process, the air pollutants in Baoding and Shijiazhuang, Tangshan and Langfang were not easy to spread due to adverse weather conditions and the special geographical location, causing the accumulation of air pollutants in this pollution.

\section{Meteorology in Baoding}

From Fig. 6, it can be seen that the AQI rose significantly when the relative humidity rose. As the conclusion in 3.1.1, particulate matter was the major

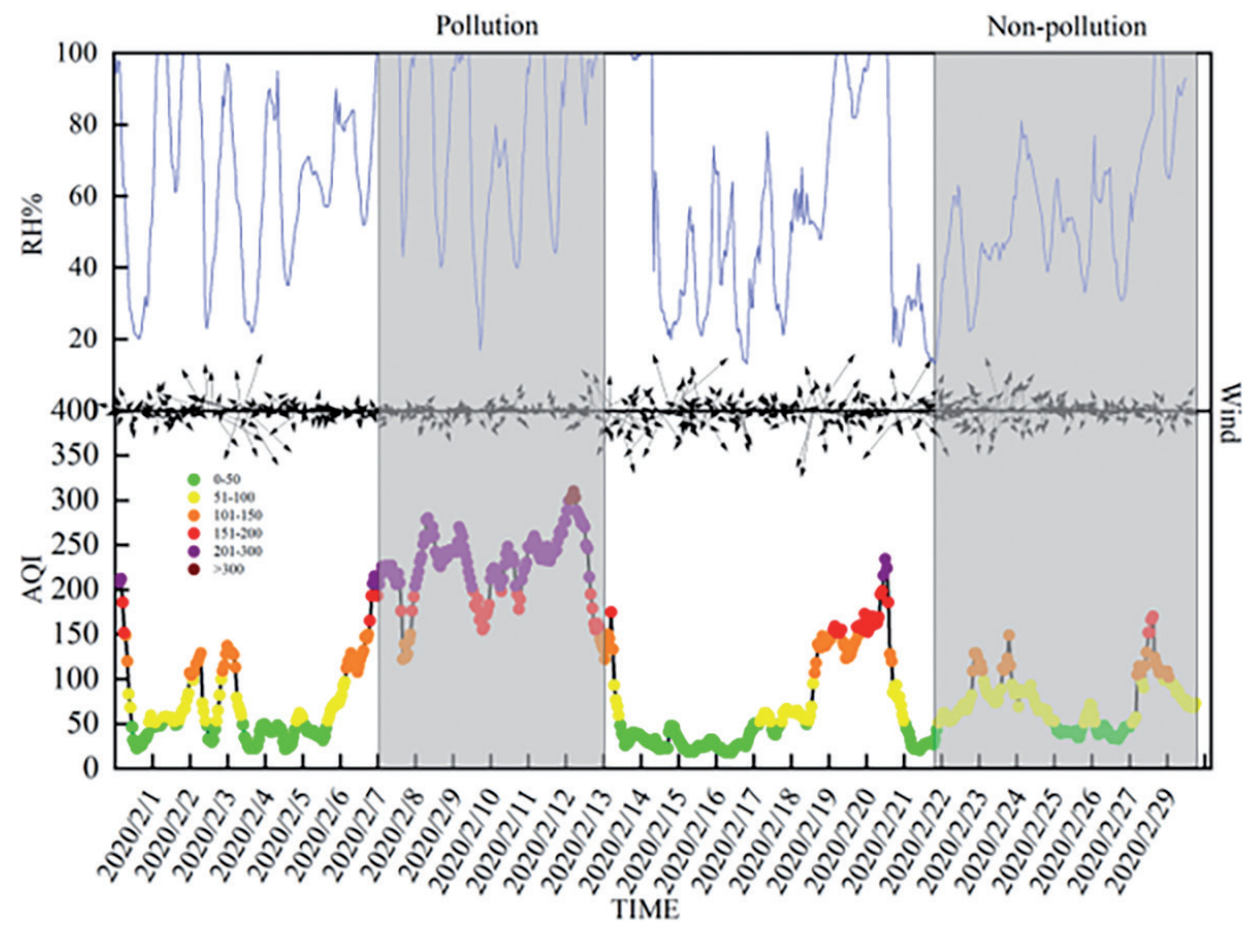

Fig. 6. AQI, relative humidity and wind vector changes in Baoding on February 8 to 13, 2020. 
pollutant that caused AQI to rise during COVID-19. The high humidity condition could promote the moisture absorption of aerosols, and the conversion of gaseous precursors to secondary particles, causing the cumulation of particle concentration [13-16, 58]. In addition, the wind speed during the heavy pollution period $\left(\right.$ speed $_{\text {average }}=1.4 \mathrm{~m} / \mathrm{s}$, speed max $\left._{\text {mas }}=4.4 \mathrm{~m} / \mathrm{s}\right)$ was obviously lower than that during non-pollution period $\left(\right.$ speed $_{\text {average }}=2.8 \mathrm{~m} / \mathrm{s}$, speed $\left.{ }_{\max }=8.4 \mathrm{~m} / \mathrm{s}\right)$. It's because the low wind speed provided a relatively stable physical environment for the formation of secondary particles.

\section{Backward Trajectory Analysis}

Fig. 7 showed the backward trajectory of the heavy pollution period and the non-pollution period in February. It can be seen that during the heavy pollution period, the airflow trajectory principally passed through some cities in Inner Mongolia, Henan, and Hebei. Among them, the backward trajectory of airflow from the southwest of Baoding (Shijiazhuang and nearby cities) was short, slower, and the airflow trajectory stayed in these areas for a long time, which was easy to carry suspended particles along the way to Baoding. The other part mainly came from the northwest, passing through Inner Mongolia and Tianjin to Baoding through long-distance transportation process. This part of airflow trajectories had small distribution areas, and long paths which had a certain impact on Baoding. In the non-pollution period, the airflow trajectory path was significantly longer, these airflow trajectories were faster, and the residence time was shorter, which was difficult to carry a large amount of particles to Baoding, and the air quality was improved. Moreover, the results of cluster analysis showed that Baoding was mainly affected by two air masses during the heavy pollution period, one of them was from the northwest and the other was from the southwest. Among them, air masses from southwestern Hebei Province accounted for the largest proportion $(79.9 \%)$. This part of the region was densely populated, developed in industry, and had many anthropogenic pollution sources, which caused the accumulation of particulate matter during the transportation process. The air masses transported suspended particulate matter from areas along the way to Baoding, aggravating the pollution of Baoding. The other airflow was followed by the Inner Mongolia long-distance air masses from the northwest, which accounted for only $20.1 \%$, but the $\mathrm{PM}_{2.5}$ concentration carried was slightly higher than the southwest, which also had a certain impact on the air quality of Baoding.

In order to identify the potential source areas of $\mathrm{PM}_{2.5}$ in Baoding, CWT analysis were used in this study. The darker the grid color, the greater the impact of the grid's source area on Baoding's pollution. The results showed that during the heavy pollution period, potential pollution source regions were mainly distributed in Shijiazhuang, Handan and Xingtai, followed by some cities in the northwest of Shanxi (Fig. 8). During the non-pollution period, Baoding was mainly affected by three air masses, and the air masses from the northwest, southwest and east accounted for 5.7\%, 51.6\% and $42.7 \%$ respectively. From the results of the backward trajectory analysis, it can be seen that the concentration of pollutants carried by the three air masses was not high. The main potential source areas affecting Baoding were in the south and west of Baoding.

It can be seen that the concentration of particulate matter and CO during the heavy pollution period were significantly higher than that of the non-pollution period, especially particulate matter (Table 4). The air mass transmission from southwest of Baoding made a certain contribution during the heavy pollution period. The analysis of water-soluble ions in the previous studies have shown that the concentration of $\mathrm{K}^{+}$in Baoding and Shijiazhuang both increased significantly during the Lantern Festival. Shijiazhuang is in the southwest direction of Baoding. The air mass in this
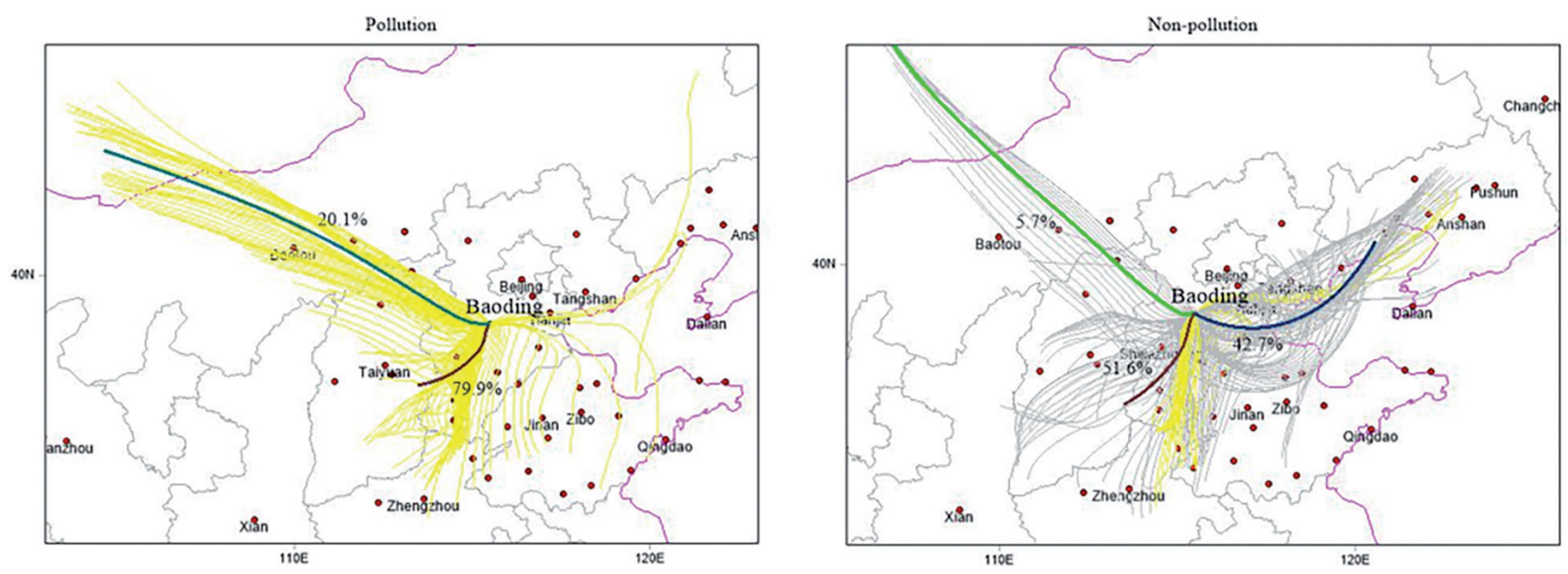

Fig. 7. Backward trajectory analysis of the heavy pollution and non-pollution periods in February. (The trajectory which $\mathrm{PM}_{2.5}$ hourly concentration exceeds $75 \mu \mathrm{g} \cdot \mathrm{m}^{-3}$ is yellow, otherwise it is gray.) 

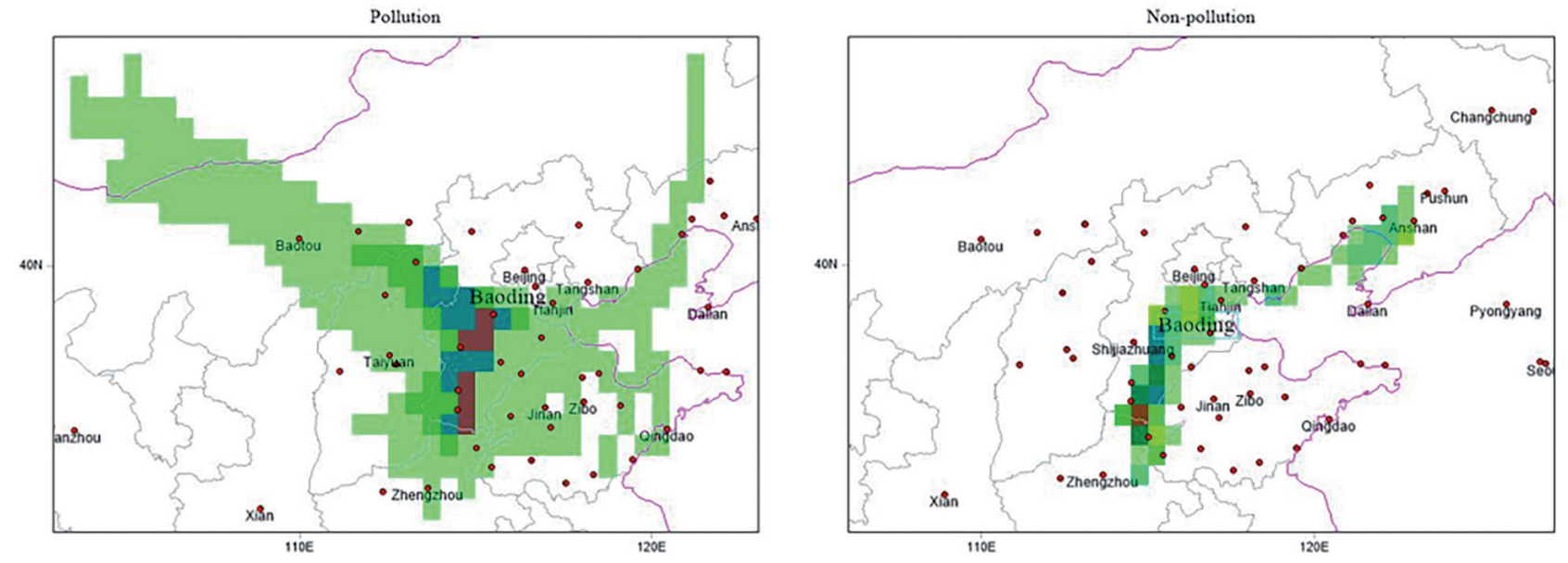

Fig. 8. Analysis of potential sources during the heavy pollution period and non-pollution period in February.

Table 4. Cluster analysis of air pollutants during the heavy pollution period and non-pollution period.

\begin{tabular}{|c|c|c|c|c|c|c|c|}
\hline Month & Air mass direction & $\mathrm{PM}_{2.5}$ & $\mathrm{PM}_{10}$ & $\mathrm{SO}_{2}$ & $\mathrm{NO}_{2}$ & $\mathrm{CO}$ & $\mathrm{O}_{3}$ \\
\hline \multirow{3}{*}{ Pollution } & Southwest (79.9\%) & 176 & 210 & 13 & 39 & 2.2 & 62 \\
\cline { 2 - 9 } & Northwest (20.1\%) & 180 & 213 & 11 & 29 & 2.2 & 51 \\
\hline \multirow{3}{*}{ Non-pollution } & Northwest (5.7\%) & 14 & 28 & 5 & 12 & 0.2 & 74 \\
\cline { 2 - 9 } & Southwest (51.6\%) & 56 & 76 & 10 & 29 & 0.7 & 50 \\
\cline { 2 - 9 } & Northeast (42.7\%) & 45 & 70 & 13 & 29 & 0.6 & 55 \\
\hline
\end{tabular}

direction carried the particles from Shijiazhuang to Baoding. The superimposed effects of transmission and local emissions in Baoding have caused heavy pollution. In the analysis of potential sources for Jing-Jin-Ji, it was found that the local $\mathrm{PM}_{2.5}$ pollution emission contribution of Baoding accounted for about $60.0-70.0 \%$, and the winter was mainly affected by air masses from the northwest and south directions [59], it's similar to the situation in this pollution period; Zhang et al. [18] analyzed the potential source of $\mathrm{PM}_{2.5}$ in Beijing, and found that Hebei Province was the potential source area in spring and autumn, while the winter was mainly affected by local emissions, indicating that during the heavy pollution period, Jing-Jin-Ji was greatly affected by local emissions; Li et al. [60] used the PSCF and the CWT to analyze the potential sources of $\mathrm{PM}_{10}$ and $\mathrm{PM}_{2.5}$ in Beijing, and found that the potential source area of $\mathrm{PM}_{10}$ was similar to that of $\mathrm{PM}_{25}$. Through backward trajectory analysis, Wang et al. [61] found that the air circulation in Beijing, Tangshan, Tianjin, Langfang, Baoding, and Cangzhou was very strong, indicating that the transport of pollutants between these cities was relatively strong, which lead to the mutual influence of the atmospheric environment between cities. In this study, it can be concluded that Baoding was mainly affected by the polluted air masses in Shijiazhuang, Xingtai and Handan during the heavy pollution period.

\section{Conclusions}

In this study, it can be seen that there was a heavy pollution during COVID-19 outbreak in Baoding. As the data shows, during the heavy pollution period, the concentrations of $\mathrm{PM}_{2.5}$ exceeded the national secondary standards, and the main contributors to this pollution were 3.7 times that of the non-pollution period. The concentration of carbon-containing components and water-soluble ions in $\mathrm{PM}_{2.5}$ indicates that the pollution which impacts the concentration of $\mathrm{PM}_{2.5}$ are from the burning of civilian coal and the Lantern Festival fireworks, respectively. Moreover, the unfavorable weather conditions made pollutants accumulate locally in Baoding, causing long-term pollution. Therefore, in addition to local emissions, this heavy pollution process in Baoding also had the dual effects of regional transmission and local unfavorable diffusion weather conditions. This study highlights the importance of local emission, regional transportation and meteorology in designing control strategies.

\section{Acknowledgments}

This work was supported by the National Research Program for Key Issues in Air Pollution Control (No. DQGG0304-05) and the Fundamental Research Funds 
for Central Public Welfare Scientific Research Institutes of China (No. 2016YSKY-025).

\section{Conflict of Interest}

The authors declare no conflict of interest.

\section{References}

1. WANG P., CHEN K., ZHU S., WANG P., ZHANG H. Severe air pollution events not avoided by reduced anthropogenic activities during COVID-19 outbreak. Resources, Conservation \& Recycling. 158, 104814, 2020.

2. HAN R., WANG S., SHEN W., WANG J., WU K., REN Z., FENG M. Spatial and temporal variation of haze in China from 1961 to 2012. Journal of Environmental Sciences. 46, 134, 2016.

3. CHEN X., ZHANG L.W., HUANG J.J., SONG F.J., ZHANG L.P., QIAN Z.M., TREVATHAN E., MAO H.J., HAN B., VAUGHN M. Long-term exposure to urban air pollution and lung cancer mortality: A 12-year cohort study in Northern China. Science of the Total Environment. 571, $855,2016$.

4. XU W., SUN Y., CHEN C., DU W., HAN T., WANG Q., FU P., WANG Z., ZHAO X., ZHOU L., JI D., WANG P., WORSNOP D. Aerosol composition, oxidation properties, and sources in Beijing: results from the 2014 Asia-Pacific Economic Cooperation summit study. Atmospheric Chemistry and Physics. 15 (23), 13681, 2015.

5. CHAI F., GAO J., CHEN Z., WANG S., ZHANG Y., ZHANG J., ZHANG H., YUN Y., REN C. Spatial and temporal variation of particulate matter and gaseous pollutants in 26 cities in China. Journal of Environmental Sciences. 26 (1), 75, 2014.

6. CHENG Z., WANG S., JIANG J., FU Q., CHEN C., XU B., YU J., FU X., HAO J. Long-term trend of haze pollution and impact of particulate matter in the Yangtze River Delta, China. Environmental Pollution. 182, 101, 2013.

7. China, S. C. o. t. P. s. R. o. Notice of the general office of the state council on issuing the air pollution prevention and control action plan. 2019. http://www.gov.cn/zwgk/201309/12/content 2486773.htm.

8. CAO J., DING A., GAO J., FU Q., HUO J., LIU B., LIU Z., YANG F., HE K., HAO J. Drivers of improved PM $_{2.5}$ air quality in China from 2013 to 2017. Proceedings of the National Academy of Sciences. (USA) 116 (49), 24463-, 2019.

9. China, M. o. E. a. E. o. t. P. s. R. o. 2017 Report on the state of the ecology and environment in China. 2019. http://english.mee.gov.cn/Resources/Reports/soe/ SOEE2017/201808/P020180801597738742758.pdf.

10. ZHANG K., LV W., WANG WAN., WANG J., DUAN J., DI W., MENG F. Sources of Air Pollution and Effects of Coal Combustion Treatment in Baoding City. Research of Environmental Science. (China) 32 (10), 1720, 2019.

11. MA T., DUAN F., HE K., QIN Y., TONG D., GENG G., LIU X., LI H., YANG S., YE S., XU B., ZHANG Q., MA Y. Air pollution characteristics and their relationship with emissions and meteorology in the Yangtze River Delta region during 2014-2016. Journal of Environmental Sciences. 83, 8, 2019.
12. LI J., LIAO H., HU J., LI N. Severe particulate pollution days in China during 2013-2018 and the associated typical weather patterns in Jing-Jin-Ji and the Yangtze River Delta regions. Environmental Pollution. 248 (2), 74, 2019.

13. WANG Y.J., BAO S.W., WANG S.X., HU Y.T., SHI X., WANG J.D., ZHAO B., JIANG J.K., ZHENG M., WU M.H., RUSSELL ARMISTEA D.G., WANG Y.H., HAO J.M. Local and regional contributions to fine particulate matter in Beijing during heavy haze episodes. Science of the Total Environment. 580, 283, 2017.

14. LIU P.F., ZHAO C.S., GOBEL T., HALLBAUER E., NOWAK A., RAN L., XU W.Y., DENG Z.Z., MA N., MILDENBERGER K., HENNING S., STRATMANN F., WIEDENSOHLER A. Hygroscopic properties of aerosol particles at high relative humidity and their diurnal variations in the North China Plain. Atmospheric Chemistry and Physics. 11 (1), 3479, 2011.

15. KUMAR P., HOPKE P.K., RAJA S., CASUCCIO G., LERSCH T.L., WEST R.R. Characterization and heterogeneity of coarse particles across an urban area. Atmospheric Environment. 46, 449, 2012.

16. LAGUDU U.R.K., RAJA S., HOPKE P.K., CHALUPA D.C., UTELL M.J., CASUCCIO G., LERSCH T.L., WEST, R.R. Heterogeneity of coarse particles in an urban area. Environmental Science and Technology. 45 (8), 3288, 2011.

17. YANG J., JI Z., KANG S., ZHANG Q., CHEN X., LEE S.Y. Spatiotemporal variations of air pollutants in western China and their relationship to meteorological factors and emission sources. Environmental Pollution. 254, 112952, 2019.

18. ZHANG Y.L., CAO F. Fine particulate matter $\left(\mathrm{PM}_{2.5}\right)$ in China at a city level. Scientific Reports. 5, 14884, 2015.

19. GAO L.J., TIAN Y.Z., ZHANG C.Y., SHI G.L., HAO H.Z., ZENG F., SHI C.L., ZHANG M.G., FENG Y.C., LI $\mathrm{X}$. Local and long-range transport influences on $\mathrm{PM}_{2.5}$ at a cities-cluster in northern China, during summer 2008. Particuology. 13, 66, 2014.

20. PERRONE M.R., BECAGLI S., GARCIA ORZA J.A., VECCHI R., DINOI A., UDISTI R., CABELLO M. The impact of long-range-transport on $\mathrm{PM}_{1}$ and $\mathrm{PM}_{2.5}$ at a central mediterranean site. Atmospheric Environment. 71, 176, 2013.

21. GUI K., CHE H., WANG Y., WANG H., ZHANG L., ZHAO H., ZHENG Y., SUN T., ZHANG X. Satellitederived $\mathrm{PM}_{2.5}$ concentration trends over Eastern China from 1998 to 2016: Relationships to emissions and meteorological parameters. Environmental Pollution. 247, 1125, 2019.

22. SHI C., YUAN R., WU B., MENG Y., ZHANG H., ZHANG H., GONG Z. Meteorological conditions conducive to $\mathrm{PM}_{2.5}$ pollution in winter $2016 / 2017$ in the Western Yangtze River Delta, China. Science of the Total Environment. 642, 1221, 2018.

23. CAI Z., JIANG F., CHEN J., JIANG Z., WANG X. Weather condition dominates regional $\mathrm{PM}_{2.5}$ Pollutions in the Eastern Coastal Provinces of China during Winter. Aerosol and Air Quality Research. 18 (4), 969, 2018.

24. HUANG K., ZHANG X., LIN Y. The "APEC Blue" phenomenon: Regional emission control effects observed from space. Atmospheric Research. 164-165, 65-75, 2015.

25. LI X., QIAO Y., ZHU J., SHI L., WANG Y.T. The "APEC blue" endeavor: causal effects of air pollution regulation on air quality in China. Journal of Cleaner Production. 168, 1381, 2017. 
26. SUN Y., WANG Z., WILD O., XU W., CHEN C., FU P., DU W., ZHOU L., ZHANG Q., HAN T., WANG Q., PAN, X., ZHENG H., LI J., GUO X., LIU J., WORSNOP D.R. "APEC Blue": secondary aerosol reductions from emission controls in Beijing. Scientific Reports. 6, 20668, 2016.

27. WANG H., ZHAO L., XIE Y., HU Q. "APEC blue" - The effects and implications of joint pollution prevention and control program. Science of the Total Environment. 553, 429, 2016.

28. LI H., ZHANG Q., DUAN F., ZHENG B., HE K.B. The "Parade Blue": effects of short- term emission control on aerosol chemistry. Faraday Discussions. 189, 317, 2016.

29. XU W., SONG W., ZHANG Y., LIU X., ZHANG L., ZHAO Y., LIU D., TANG A., YANG D., WANG D., WEN Z., PAN Y., FOWLER DAVID, COLLETT JEFFERY L. JR., ERISMAN JAN WILLEM, GOULDING KEITH, LI Y., ZHANG F. Air quality improvement in a megacity: implications from 2015 Beijing Parade Blue pollution control actions. Atmospheric Chemistry and Physics. 17 (1), 31, 2017.

30. XUE Y., WANG Y., LI X., TIAN H., NIE L., WU X., ZHOU J., ZHOU Z. Multi-dimension apportionment of clean air "parade blue" phenomenon in Beijing. Journal of Environmental Sciences. 65, 29, 2018.

31. WANG G., CHENG S., WEI W., YANG X., WANG X., JIA J., LANG J., LV Z. Characteristics and emissionreduction measures evaluation of $\mathrm{PM}_{2.5}$ during the two major events: APEC and Parade. Science of the Total Environment. 595, 81, 2017.

32. CASTRO L.M., PIO C.A., HARRISON R.M., SMITH D.J.T. Carbonaceous Aerosol in Urban and Rural European Atmospheres: Estimation of Secondary Organic Carbon Concentrations. Atmos. Environ. 33, 2771, 1999.

33. ZHANG L.Y., YIMIN HUANG., YUAN LIU., FUMO YANG., GUOXIN LAN., CHUAN FU., JUN WANG Characteristics of Carbonaceous Species in $\mathrm{PM}_{25}$ in Wanzhou in the Hinterland of the Three Gorges Reservior of Northeast Chongqing, China. Atmosphere. 6 (4), 534, 2015.

34. WANG Y.Q., ZHANG X.Y., ARIMOTO R. The contribution from distant dust sources to the atmospheric particulate matter loadings at Xi'an, China during spring. Science of the Total Environment. 368 (2-3), 875, 2006.

35. HAO J.F., QI J.H., LI Y.Z. Analysis of Variation Characteristics of Atmospheric Particulate Matter Pollution and the Influence of Backward Trajectory in Xingtai. Environmental Monitoring. (China) 4 (05), 46, 2018.

36. WANG J., WANG G., CHEN L. Transportation Source and Transportation Process of $\mathrm{PM}_{10}$ and $\mathrm{PM}_{25}$ in Seasons of Jinan. Environmental Science \& Technology. (China) 38 (5), 175, 2015.

37. ZHANG X., ZHANG K., LIU H., LV W., AIKAWA M., LIU B., WANG J. Pollution sources of atmospheric fine particles and secondary aerosol characteristics in Beijing. Journal of Environmental Sciences. 95, 91, 2020.

38. ZHANG X., MURAKAMI T., WANG J., AIKAWA M. Sources, species and secondary formation of atmospheric aerosols and gaseous precursors in the suburb of Kitakyushu, Japan. Science of The Total Environment. 763, 143001, 2021

39. ABDULMOGITH S., HARRISON,R.M. The use of trajectory cluster analysis to examine the long-range transport of secondary inorganic aerosol in the UK. Atmospheric Environment. 39 (35), 6686, 2005.
40. BAUWENS M., COMPERNOLLE S., STAVRAKOU T. Impact of coronavirus outbreak on $\mathrm{NO}_{2}$ pollution assessed using TROPOMI and OMI observations. Geophysical Research Letters. 47 (11), 2020.

41. FAN C., LI Y., GUANG J., LI Z., LEEUW G.D. The impact of the control measures during the COVID-19 outbreak on air pollution in China. Remote Sensing. 12, 1613, 2020.

42. ZHANG R., ZHANG Y., LIN H., FENG X., FU T., WANG $\mathrm{Y} . \mathrm{NO}_{\mathrm{x}}$ emission reduction and recovery during COVID-19 in East China. Atmosphere. 11, 433, 2020.

43. LI Y.Y., YANG H.R., WANG N., LI J.X., YAO J.L. Formation analysis of a severe air pollution event in Taiyuan. Journal of Meteorology and Environment. (China) 34 (2), 11, 2018.

44. LI M., ZHANG W.J., LI CHEN Analysis of a typical heavy pollution event in winter in Jinan City. Research of Environmental Sciences. (China) 31 (11), 1867, 2018.

45. LIN H., LIU T., FANG F., XIAO J., ZENG W., LI X., GUO L., TIAN L., SCHOOTMAN M., STAMATAKIS K.A., QIAN Z., MA W. Mortality benefits of vigorous air quality improvement interventions during the periods of APEC Blue and Parade Blue in Beijing, China. Environmental Pollution. 220, 222, 2017.

46. MANCILLA Y., HERCKES P., FRASER M.P., MENDOZA A. Secondary organic aerosol contributions to $\mathrm{PM}_{2.5}$ in Monterrey, Mexico: Temporal and seasonal variation. Atmospheric Research. 153, 348, 2015.

47. SCHAUER J.J., KLEEMAN M.J., CASS G.R. Measurement of emissions from air pollution sources 5 . $\mathrm{C}_{1}-\mathrm{C}_{32}$ organic compounds from gasoline-powered motor vehicles. Environmental Science \& Technology. 36 (6), 1169, 2002

48. CHEN Y., ZHI G., FENG Y., FU J., FENG J., SHENG G., BERND R.T. SIMONEIT Measurements of emission factors for primary carbonaceous particles from residential raw-coal combustion in China. Geophysical Research Letters. 33, L20815, 2006.

49. WASTON J.G, CHOW J.C., HOUCK J.E. PM 2.5 chemical source profiles for vehicle exhaust, vegetative burning, geological material, and coal burning in Northwestern Colorado during 1995. Chemosphere. 43 (8), 1141, 2001.

50. HE Q.S., GUO W.D., ZHANG G.X. Characteristics and seasonal variations of carbonaceous species in $\mathrm{PM}_{2.5}$ in Taiyuan, China. Atmosphere. (China) 6 (6), 850, 2015.

51. WANG G., ZHANG R., GOMEZ MARIO E., YANG L., LEVY ZAMORA MISTI., HU M., LIN Y., PENG J., GUO S., MENG J., LI J., CHENG C., HU T., REN Y., WANG Y., GAO J., CAO J., AN Z., ZHOU W., LI G., WANG J., TIAN P., MARRERO-ORTIZ WILMARIE., SECREST JEREMIAH, DU Z., ZHENG J., SHANG D., ZENG L., SHAO M., WANG W., HUANG Y., WANG Y., ZHU Y., LI Y., HU J., PAN BOWEN., CAI L., CHENG Y., JI Y., ZHANG F., ROSENFELD DANIEL., LISS PETER S., DUCE ROBERT A., KOLB CHARLES E., MOLINA MARIO J. Persistent sulfate formation from London Fog to Chinese haze. Proceedings of the National Academy of Sciences. (USA) V113 (48), 13630, 2016.

52. DAO X., ZHU H., TAN L., CHEN Y., WANG S., TENG E., LV Y., LI G. Variations of $\mathrm{PM}_{25}$ and its water-soluble ions in Beijing and surrounding cities during the APEC in 2014. Environmental Chemistry. (China) 34 (8), 1389, 2015.

53. LIU H., HE K.B., MA Y.L., ZHAO Q., DUAN F.K., LIANG L.L. Variations of $\mathrm{PM}_{25}$ and its water-soluble ions in urban and suburban Beijing before, during, and after the 
2008 Olympiad. Acta Scientiae Circumstantiae. (China) 31(1), 1772185, 2011.

54. CARRANZA J.E., FISHER B.T., YODER G.D., HAHAN, D.W. On-line analysis of ambient air aerosols using laserinduced breakdown spectroscopy. Spectrochimica ActaPart B Atomic Spectroscopy. 56 (6), 851, 2001.

55. KULSHRESTHA U.C., RAO T.N., AZHAGUVEL S., KULSHRESTHA M.J. Emissions and accumulation of metals in the atmo atmosphere due to crackers and sparkles during Diwali festival in India. Atmospheric Environment. 38, 4421, 2004.

56. LV W.L., ZHANG K., CAO Q., ZHU S., CHEN J.H., ZHI M.K., LI D. Impacts of fireworks burning on atmospheric pollutants and water-soluble inorganic ions in $\mathrm{PM}_{2.5}$. China Environmental Science. 40 (8), 3303, 2020.

57. ZHU G., ZHANG L., CHEN L. Characteristic analysis of heavy pollution process in Hebei Province in 2015. Coal and Chemical Industry. (China) 40 (12), 143, 2017.
58. CHEN Z., CAI J., GAO B., XU B., DAI S., HE B., XIE X. Detecting the causality influence of individual meteorological factors on local $\mathrm{PM}_{2.5}$ concentration in the Jing-Jin-Ji region. Science Reports. 7, 40735, 2017.

59. ZHENG Y., CHENG F., ZHANG K., TANG WEI, MENG F., LI P., GUO Z. Characteristics and Potential Transport Source Identification of Atmospheric Pollution in Baoding City. Research of Environmental Sciences. (China) 33 (2), 260, 2020.

60. LI M., LIU H., GENG G.N., HONG C.P., LIU F., SONG Y., TONG D., ZHENG B., CUI H.Y., MAN H.Y., ZHANG Q., HE K.B. Corrigendum to Anthropogenic emission inventories in China: a review. National Science Review. 4 (6), 834, 2017.

61. WANG G., WANG D., CHEN Z. Characteristics and transportation pathways and potential sources of a severe $\mathrm{PM}_{2.5}$ episodes during winter in Beijing. (China) China Environmental Science. 36 (7), 1931, 2016. 